\title{
Effects of Ambient Parameters on the Performance of a Direct-Expansion Solar-Assisted Heat Pump with Bare Plate Evaporators for Space Heating
}

\author{
Wenzhu Huang, Jie Ji, Mawufemo Modjinou, and Jing Qin \\ Department of Thermal Science and Energy Engineering, University of Science and Technology of China, No. 96 Jinzhai Road, \\ Hefei City, Anhui Province, China \\ Correspondence should be addressed to Jie Ji; jijie@ustc.edu.cn
}

Received 29 December 2016; Revised 3 June 2017; Accepted 4 July 2017; Published 1 October 2017

Academic Editor: Michel Feidt

Copyright ( 2017 Wenzhu Huang et al. This is an open access article distributed under the Creative Commons Attribution License, which permits unrestricted use, distribution, and reproduction in any medium, provided the original work is properly cited.

\begin{abstract}
Research on the direct-expansion solar-assisted heat pump (DX-SAHP) system with bare plate evaporators for space heating is meaningful but insufficient. In this paper, experiments on a DX-SAHP system applying bare plate evaporators for space heating are conducted in the enthalpy difference lab with a solar simulator, with the ambient conditions stable. The independent effects of ambient temperature, solar irradiation, and relative humidity on the system performance are investigated. When ambient temperature changes as $5^{\circ} \mathrm{C}, 10^{\circ} \mathrm{C}$, and $15^{\circ} \mathrm{C}$, COP increases as $2.12,2.18$, and 2.26 . When solar irradiance changes as $0 \mathrm{~W} \mathrm{~m}^{-2}$, $100 \mathrm{~W} \mathrm{~m}^{-2}, 200 \mathrm{~W} \mathrm{~m}^{-2}, 300 \mathrm{~W} \mathrm{~m}^{-2}$, and $500 \mathrm{~W} \mathrm{~m}^{-2}$, COP of the system changes as 2.07, 2.09, 2.14, 2.26, and 2.36. With ambient temperature of $5^{\circ} \mathrm{C}$ and solar irradiance of $0 \mathrm{~W} \mathrm{~m}^{-2}$, when relative humidity is $50 \%$, no frost formed. Whereas with relative humidity of $70 \%$ and $90 \%$, frost formed but not seriously frosted after 120 min of operating. Frost did not deteriorate but improved the heating performance of the DX-SAHP system. The change of relative humidity from $70 \%$ to $90 \%$ improves the evaporating heat exchange rate by $35.0 \%$ and increases COP by $16.3 \%$, from 1.78 to 2.07 .
\end{abstract}

\section{Introduction}

Energy consumed for space heating is a large part of domestic energy consumption. The idea of using solar energy is one of the methods to face the energy crisis, since it is renewable and clean. To introduce solar energy into space heating, solarassisted heat pump system was proposed. Solar-assisted heat pump systems can effectively utilize solar energy and perform better than conventional heat pumps. Many researches have been published on solar-assisted heat pumps [1-5].

Sporn et al. proposed the idea of direct-expansion solar-assisted heat pump (DX-SAHP), as one type of solarassisted heat pumps [6]. The components in DX-SAHP systems are reduced compared to that in indirect-expansion solar-assisted heat pumps, because refrigerant absorbs heat directly in the collectors of the system, which work as the evaporator. DX-SAHP is promising due to the advantages of having low cost and nonfreeze-up at nighttime. Lots of researches have been reported on DX-SAHP [7-13].
Chaturvedi and Shen [7] proved that DX-SAHP had better performance compared to traditional heat pump systems, with COP range of 2 to 3. Huang and Chyng [8] built an integral type solar-assisted heat pump water heater with a collector/evaporator and a thermosyphon heat exchanger. The COP of the system was 2.5-3.7 at water temperature between $61^{\circ} \mathrm{C}$ and $25^{\circ} \mathrm{C}$. Krakow and Lin [9] studied the performance of the direct-expansion solar source heat pump systems with solar collectors. They concluded that the system was promising to utilize solar energy in cold climates. Ito et al. [10] analyzed and optimized the structure parameters of a DX-SAHP system in theoretical and experimental methods. Hawlader et al. [11] paid attention to the effect of the volume of water tank on the performance of a DX-SAHP water heater. Chyng et al. [12] theoretically researched the annual performance of an integrated solar-assisted heat pump water heater with a bare collector. Xu et al. [13] simulated the operating performance of a DX-SAHP water heater using the meteorological data in Nanjing. They showed that the system could heat 
$150 \mathrm{~L}$ of water to $55^{\circ} \mathrm{C}$ efficiently under various weather conditions at different time of the year.

Recently, Li et al. [14] compared two DX-SAHP water heater systems. An optimization method for the collector was concluded. They also suggested that variable frequency compressor and electronic expansion valve should be applied in the system. A DX-SAHP water heater was numerically simulated by Kong et al. [15]. It is concluded that wind speed has no great effect on the system performance. Chow et al. [16] developed a theoretical model of a DX-SAHP water heater with an unglazed solar collector. They simulated the performance of the system in a whole year, obtained a yearlong average COP of 6.46 in Hong Kong, and proved the system promising. Sun et al. [17] designed and tested a DXSAHP water heating system using an optimized-channel roll-bond collector/evaporator. They proved the roll-bond panel with optimized channel pattern could improve the performance of the DX-SAHP system significantly. The performance of a DX-SAHP water heater with integral storage tank with solar irradiance of zero was experimentally investigated [18]. The solar collectors were installed in a climate chamber to work at stable ambient air temperature. Applying the Huang and Lee's performance evaluation method, the characteristic COP for the system is 3.23 under zero solar irradiance conditions at a water-ambient air temperature difference of $15^{\circ} \mathrm{C}$. Kuang and Wang [19] tested a DX-SAHP system for domestic use. The system can operate under space heating mode, air conditioning mode, and water heating mode. Space heating was realized by radiant floor heating unit. The experiment data revealed that the system reached COP of 2.6 to 3.3 for space heating and could supply $200 \mathrm{~L}$ or $1000 \mathrm{~L}$ hot water daily under various weather conditions. Zhang et al. [20] analyzed the effect of R22, R134a, and R744 on the performance of a solar-air hybrid heat source heat pump water heater. They pointed out that three refrigerants had a similar operating performance.

On one hand, the published researches mostly focused on DX-SAHP for water heating instead of space heating. However, the application of DX-SAHP for space heating is also common. But the system performance under this condition has not been researched sufficiently, because the heating capacity is difficult to measure. On the other hand, the most experimental researches on DX-SAHP were tested in outdoor environment. The shortcoming is that the experiments are unrepeatable and unable to present accurate parametric analysis. The experimental study with the system of the four features, as direct-expansion, solar-assisted, space heating, and steady environment is rare. In this paper, a DX-SAHP system for space heating is experimentally studied under stable conditions. During the experiments, the ambient temperature, solar irradiation, and relative humidity were controlled to be constant in the enthalpy difference lab with a solar simulator. Previous investigation [21] showed that DX-SAHP with bare plate evaporators was applicable under frosting conditions but the performance of the system was not sufficiently investigated. Bare plate evaporators also have the advantages of low cost and simple structure. Therefore, bare plate evaporators are selected for the tested system. Based on the experimental data, parametric analysis is conducted, including ambient temperature, solar irradiation, and relative humidity. The data can be referenced for further experimental and theoretical study of DX-SAHP. The conclusions may benefit the design and optimization of DX-SAHP systems of similar structure.

\section{Experimental Setup}

Using the enthalpy difference lab, which is the standard testing lab for heat pumps, stable test conditions could be realized. The DX-SAHP prototype for space heating is installed in the two chambers of the enthalpy difference lab, as shown in Figure 1(a). The condenser of the DX-SAHP system is the air heat exchanger in the indoor chamber. It is connected directly to the air-enthalpy type calorimeter. Therefore, the heating capacity of the system can be measured and the space heating performance can be analyzed. A rotary-type hermetic compressor with rated input power of $750 \mathrm{~W}$ is used, and the refrigerant is R22. In the outdoor chamber, the solar simulator is installed, to generate stable and controllable solar irradiation on the solar collectors, with the instability and heterogeneity under $\pm 5 \%$. The spectrum distribution of the solar simulator meets the China National Class B level standard and can simulate solar irradiation in solar thermal research. The luminous area is $2 \times 2 \mathrm{~m}^{2}$, perfectly covering the collectors.

Bare plate evaporators have advantages such as low cost, easy manufactural structure, and slow frosting rate, but DXSAHP systems with bare plate evaporators are not sufficiently researched. Therefore, two bare flat plate collectors are applied in the experimental prototype of DX-SAHP. The temperature, pressure, solar irradiation, ambient temperature, relative humidity, and heating capacity of the system were measured and recorded. The specifications of the measurement instruments and more detailed experimental settings were presented in our previous work [21].

\section{Experimental Procedure and Thermodynamic Analysis Methods}

3.1. Experimental Procedure. To research the independent influence of the ambient parameters on the performance of the DX-SAHP system, specific stable conditions were arranged during the experiments, with the help of the enthalpy difference lab with a solar simulator. In the outdoor chamber, the ambient are under winter meteorological conditions. The ambient temperature was chosen as $5^{\circ} \mathrm{C}, 10^{\circ} \mathrm{C}$, and $15^{\circ} \mathrm{C}$ when the relative humidity was maintained as $50 \%$ and solar irradiance was $300 \mathrm{~W} \mathrm{~m}^{-2}$; solar irradiance was $0 \mathrm{~W} \mathrm{~m} \mathrm{~m}^{-2}, 100 \mathrm{~W} \mathrm{~m}^{-2}, 200 \mathrm{~W} \mathrm{~m}^{-2}, 300 \mathrm{~W} \mathrm{~m}^{-2}$, and $500 \mathrm{~W} \mathrm{~m}^{-2}$ when the ambient temperature was $15^{\circ} \mathrm{C}$ and the relative humidity was $50 \%$; the ambient temperature was $5^{\circ} \mathrm{C}$ and solar irradiance $0 \mathrm{~W} \mathrm{~m}^{-2}$ was when the relative humidity was $50 \%, 70 \%$, and $90 \%$. When solar irradiance was higher, more thermal load was produced by the solar simulator, and it got harder for the enthalpy difference lab to maintain a constant ambient temperature. Therefore, solar irradiance higher than $500 \mathrm{~W} \mathrm{~m}^{-2}$ was not tested in the experiments. According to GB/T 7725-2004 


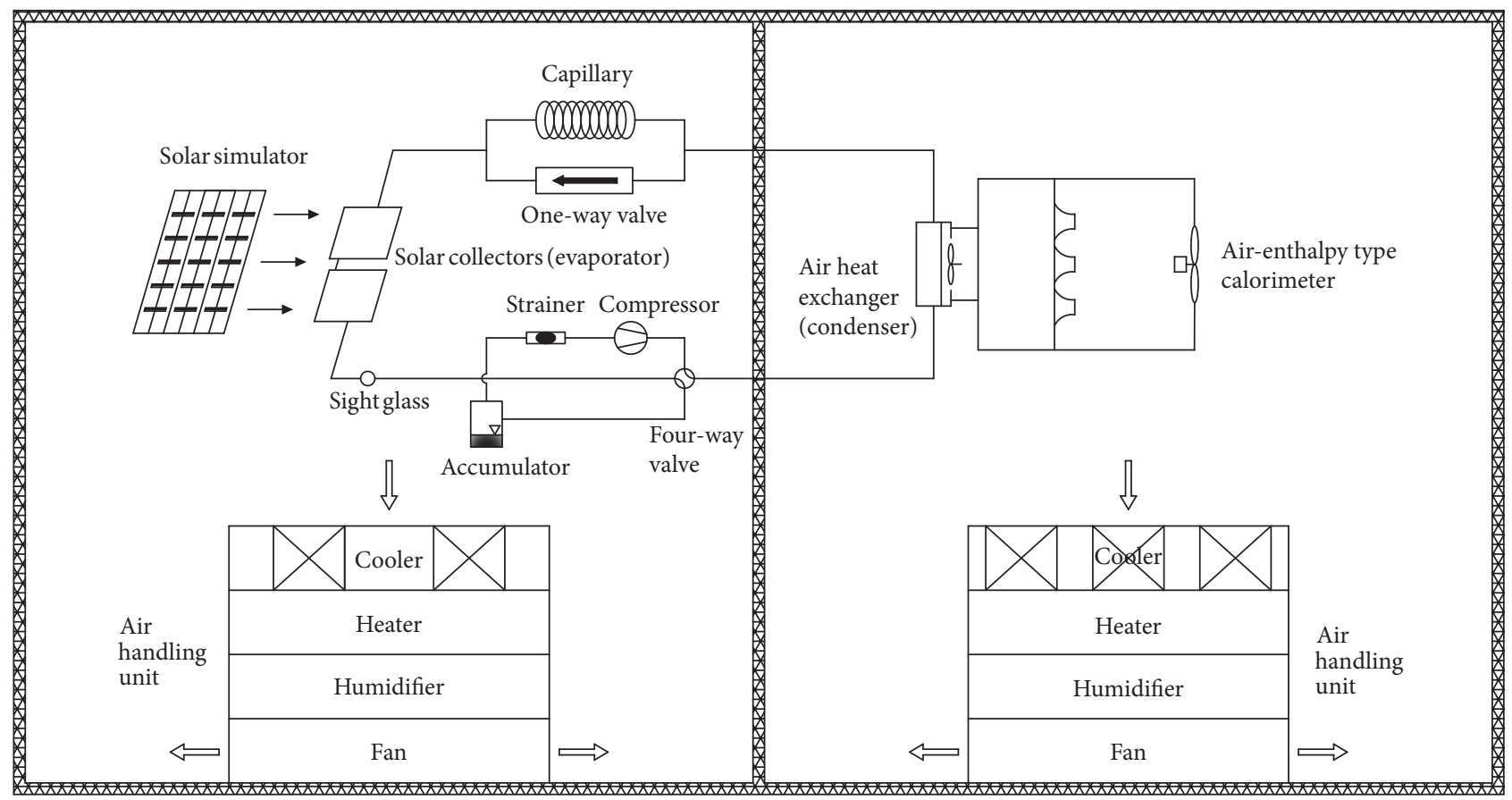

Outdoor chamber

Indoor chamber

(a)
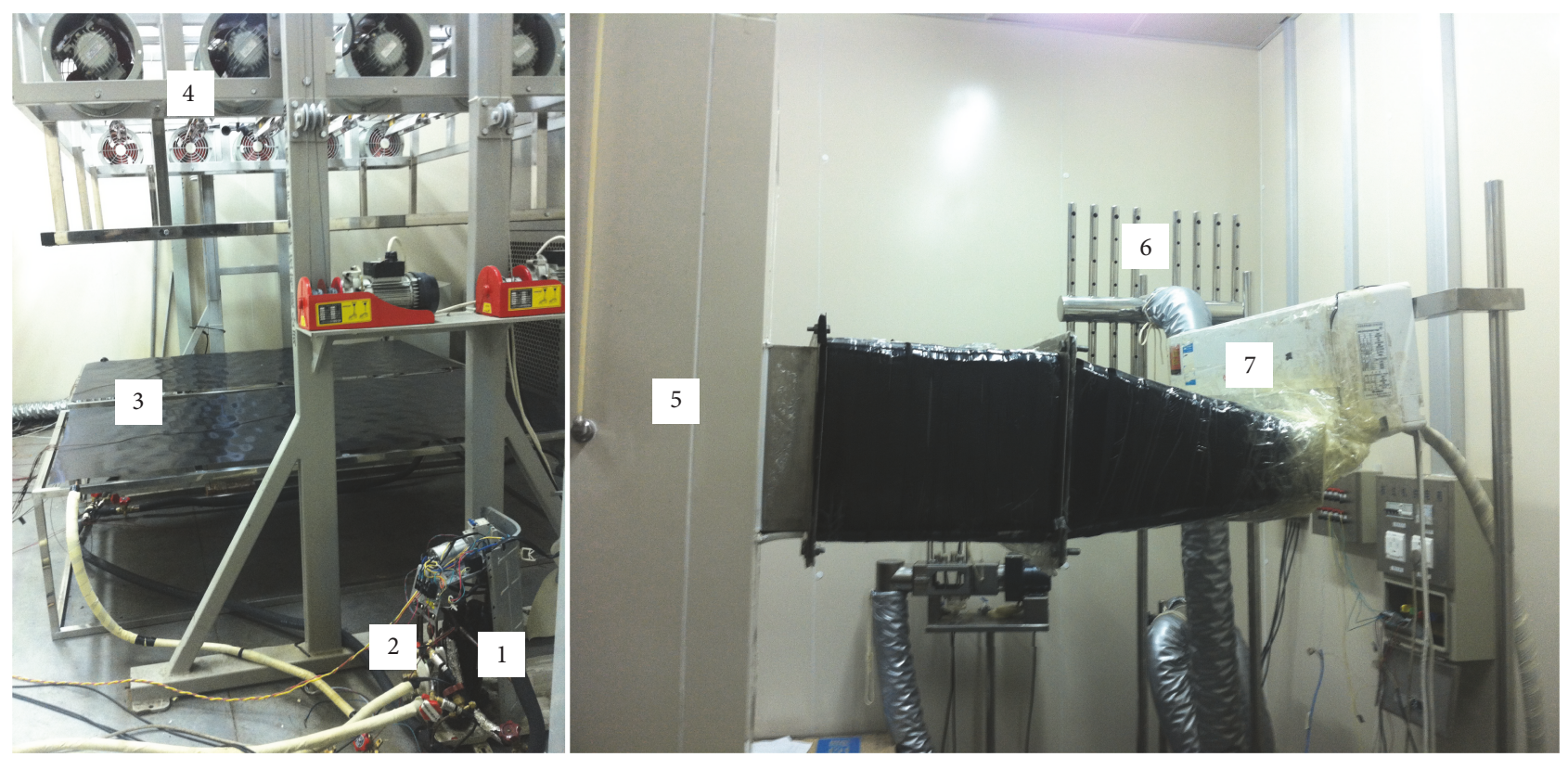

(b)

Figure 1: (a) A schematic diagram of the enthalpy difference lab and the tested system (b) photo of the DX-SAHP system. (1) Compressor; (2) capillary tube; (3) bare plate evaporators; (4) solar simulator; (5) air-enthalpy type calorimeter; (6) indoor sampling device; (7) indoor air heat exchanger.

(the National Standard of China for air conditioners), the indoor temperature was chosen as $20^{\circ} \mathrm{C} / 15^{\circ} \mathrm{C}$ (dry bulb/ wet bulb).

In the experiments, as the first step, the ambient temperature and humidity of the two chambers reached the set values by the operation of the enthalpy difference lab. Then, the solar simulator was activated and generated solar irradiance, with the values adjustable. The DX-SAHP system was started afterwards and operated for $120 \mathrm{~min}$. The data acquisition system recorded the data at a 6-second interval. Because of the stable conditions, the DX-SAHP system can reach stable operating state and last till the end of the experiments. When the fluctuation of condensing heat exchange rate and energy consumption of the tested 
system is under $0.5 \%$, the system is considered as under stable operating state.

3.2. Thermodynamic Analysis Methods. To analyze the thermal performance of the DX-SAHP system, the evaporating heat exchange rate $Q_{\text {evap }}$, the condensing heat exchange rate $Q_{\text {cond }}$, and COP are needed, while the energy consumption is directly measured. For the calculation of the above parameters, the derivations of the mass and energy balance equations are applied as follows.

The mass balance equation is

$$
\sum m_{\text {in }}=\sum m_{\text {out }}
$$

The energy balance equation is

$$
Q+m_{\text {in }} h_{\text {in }}=W+m_{\text {out }} h_{\text {out }},
$$

where $Q$ is the rate of heat input, $W$ is the rate of work output, and $h_{\text {in }}$ and $h_{\text {out }}$ are the enthalpy of inlet refrigerant and outlet refrigerant.

The compression indicated power can be calculated by [22]

$$
W_{\mathrm{i}}=W_{\text {in }} \eta_{\text {comp }} \text {, }
$$

where $\eta_{\text {comp }}$ is the ratio of the compression indicated power and the compressor input power. $\eta_{\text {comp }}$ can be calculated as

$$
\eta_{\text {comp }}=\mathrm{nf} \eta_{\mathrm{el}}
$$

where $\eta_{\mathrm{el}}$ is the compression electromechanical efficiency, as 0.78. $\mathrm{nf}$ is the correction factor. The manufacturer has given the expression of $\mathrm{nf}$ as

$$
\begin{aligned}
\mathrm{nf}= & \left(0.24105+0.02868 T_{\mathrm{c}}-2.77389 E-4 T_{\mathrm{c}}^{2}\right) \\
& +1.0 E-4 \times\left(-61.10691+1.7067 T_{\mathrm{c}}\right) T_{\mathrm{e}} \\
& +1.0 E-4 \times\left(6.06781-0.10841 T_{\mathrm{c}}+0.00124 T_{\mathrm{c}}^{2}\right) T_{\mathrm{e}}^{2}
\end{aligned}
$$

where $T_{\mathrm{e}}$ is the evaporating temperature and $T_{\mathrm{c}}$ is the condensing temperature. After calculation, the approximate value of $\eta_{\text {comp }}$ is 0.75 .

For the DX-SAHP system, the energy balance equation can be written as

$$
Q_{\text {evap }}=Q_{\text {cond }}-W_{\text {in }} \eta_{\text {comp }}
$$

where $W_{\text {in }}$ is the compressor input power. In the tested system, $W_{\text {in }}$ is the energy consumption of the compressor.

According to the air-enthalpy difference method, the condensing heat exchange rate can be calculated by

$$
Q_{\text {cond }}=\frac{V_{\mathrm{a}}\left(h_{\text {in-a }}-h_{\text {out-a }}\right)}{\left[V_{\mathrm{n}}\left(1+D_{\mathrm{n}}\right)\right]} .
$$

The coefficient of performance COP can present the thermal performance of heat pump systems. COP is expressed as

$$
\mathrm{COP}=\frac{Q_{\text {cond }}}{W_{\text {in }}+W_{\text {fan }}},
$$

where $W_{\text {fan }}$ is the fan energy consumption in the condenser, as $36 \mathrm{~W}$.

As the mean value of the evaporator inlet and outlet temperatures, the evaporator temperature is written as

$$
T_{\mathrm{e}}=\frac{T_{\text {ein }}+T_{\text {eout }}}{2} \text {. }
$$

According to (9), the evaporator temperature uncertainty equals to the T-type thermocouple uncertainty, with the maximum value of $0.2^{\circ} \mathrm{C}$.

The relative error (RE) of COP and the evaporating heat exchange rate can be calculated by

$$
\begin{aligned}
& \mathrm{RE}_{Q_{\text {evap }}}=\frac{d Q_{\text {evap }}}{Q_{\text {evap }}}=\frac{d Q_{\text {cond }}+\eta d W_{\text {in }}}{Q_{\text {cond }}-\eta W_{\text {in }}}, \\
& \mathrm{RE}_{\mathrm{COP}}=\frac{d \mathrm{COP}}{\mathrm{COP}}=\left|\frac{1}{Q_{\text {cond }}}\right| d Q_{\text {cond }}+\left|\frac{1}{W_{\text {in }}}\right| d W_{\text {in }} .
\end{aligned}
$$

The experimental RE of COP is $1.3 \%$ based on (11).

\section{Results and Discussion}

As shown in Table 1, the representative tests are selected from which the independent effect of ambient temperature, solar irradiation, and relative humidity on the thermal performance of DX-SAHP can be analyzed. The data in Table 1 are the average value of the parameters during the stable operating state of the DX-SAHP system.

4.1. The Effect of Ambient Temperature. To research the influence of the ambient temperature on the thermal performance of DX-SAHP, the experiment conditions were solar irradiance of $300 \mathrm{~W} \mathrm{~m}^{-2}$ and the indoor temperature was $20^{\circ} \mathrm{C} / 15^{\circ} \mathrm{C}(\mathrm{DB} / \mathrm{WB})$, while the outdoor temperatures were $5^{\circ} \mathrm{C}, 10^{\circ} \mathrm{C}$, and $15^{\circ} \mathrm{C}$ and the relative humidity was $50 \%$. The results are shown in Figures 2-4.

Under the ambient temperature of $5^{\circ} \mathrm{C}, 10^{\circ} \mathrm{C}$, and $15^{\circ} \mathrm{C}$ and solar irradiance of $300 \mathrm{~W} \mathrm{~m} \mathrm{~m}^{-2}$, the evaporator temperature is lower than the ambient temperature, and the specific values are $3.1^{\circ} \mathrm{C}, 7.4^{\circ} \mathrm{C}$, and $12.0^{\circ} \mathrm{C}$, respectively. The evaporator temperature increases as the ambient temperature increases. Because the evaporator temperature is lower than the ambient temperature, heat transfer occurs from the ambient to the collector. Hence, the heat absorbed by the collector contains ambient heat and solar irradiation heat. It is also observed that the difference between the evaporator temperature and the ambient temperature is $1.9^{\circ} \mathrm{C}, 2.6^{\circ} \mathrm{C}$, and $3.0^{\circ} \mathrm{C}$ corresponding to the ambient temperature of $5^{\circ} \mathrm{C}, 10^{\circ} \mathrm{C}$, and $15^{\circ} \mathrm{C}$. Therefore, based on the experimental data, it can be concluded that when evaporator temperature is lower than ambient temperature, the difference between the evaporator temperature and the ambient temperature increases with the increase of the ambient temperature. Due to the increase of evaporator temperature, the evaporating pressure also increases as $415.0 \mathrm{kPa}, 426.5 \mathrm{kPa}$, and $473.9 \mathrm{kPa}$, which in turn, leads to the rise of condensing pressure, with the specific value as $1387.5 \mathrm{kPa}, 1533.3 \mathrm{kPa}$, and $1736.9 \mathrm{kPa}$. 
TABLE 1: Experimental data.

\begin{tabular}{lccccccccccc}
\hline Test number & $T_{\mathrm{a}}\left({ }^{\circ} \mathrm{C}\right)$ & $\mathrm{RH}(\%)$ & $I\left(\mathrm{~W} \cdot \mathrm{m}^{-2}\right)$ & $T_{\mathrm{e}}\left({ }^{\circ} \mathrm{C}\right)$ & $T_{\mathrm{c}}\left({ }^{\circ} \mathrm{C}\right)$ & $P_{\text {evap }}(\mathrm{kPa})$ & $P_{\text {cond }}(\mathrm{kPa})$ & $W_{\text {in }}(\mathrm{W})$ & $Q_{\text {evap }}(\mathrm{W})$ & $Q_{\text {cond }}(\mathrm{W})$ & $\mathrm{COP}$ \\
\hline 1 & 5 & 50 & 300 & 3.1 & 37.4 & 415.0 & 1387.5 & 661 & 920 & 1416 & 2.12 \\
2 & 10 & 50 & 300 & 7.4 & 42.1 & 426.5 & 1533.3 & 709 & 1005 & 1537 & 2.18 \\
3 & 15 & 50 & 500 & 16.8 & 52.1 & 590.0 & 1954.4 & 877 & 1415 & 2073 & 2.36 \\
4 & 15 & 50 & 300 & 12.0 & 46.9 & 473.9 & 1736.9 & 780 & 1181 & 1766 & 2.26 \\
5 & 15 & 50 & 200 & 11.0 & 44.2 & 444.1 & 1633.7 & 742 & 1028 & 1585 & 2.14 \\
6 & 15 & 50 & 100 & 10.0 & 41.7 & 404.2 & 1525.9 & 707 & 922 & 1452 & 2.09 \\
7 & 15 & 50 & 0 & 7.6 & 37.4 & 392.0 & 1358.3 & 632 & 835 & 1309 & 2.07 \\
8 & 5 & 50 & 0 & 0.0 & 29.6 & 282.9 & 1118.1 & 559 & 556 & 975 & 1.75 \\
9 & 5 & 70 & 0 & 0.1 & 30.2 & 298.3 & 1109.9 & 562 & 577 & 998 & 1.78 \\
10 & 5 & 90 & 0 & 2.6 & 30.4 & 303.5 & 1120.1 & 577 & 779 & 1191 & 2.07 \\
\hline
\end{tabular}

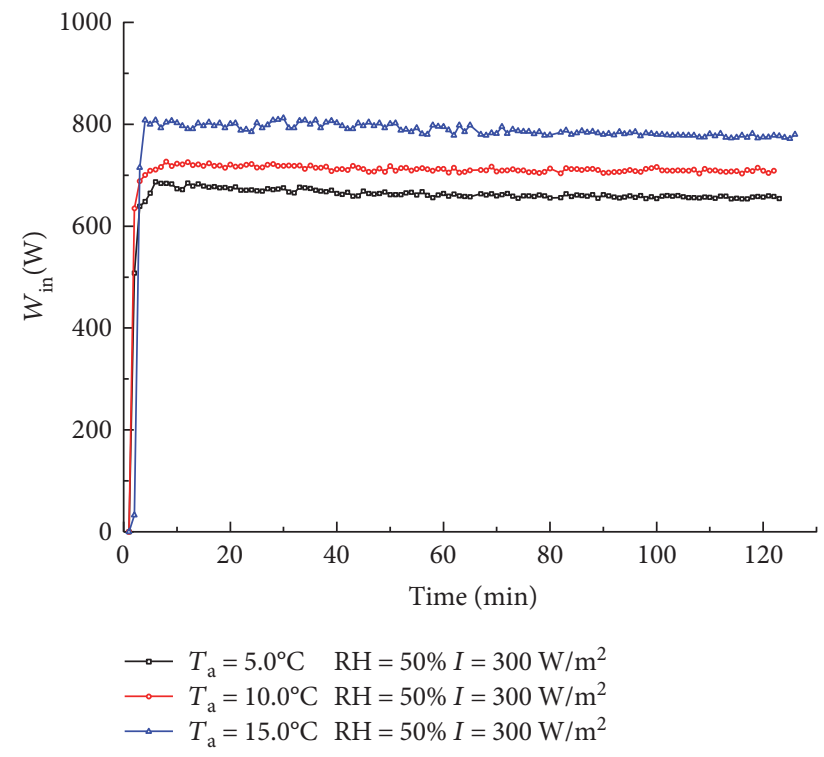

FIGURE 2: Variation of the energy consumption with the ambient temperature of $5^{\circ} \mathrm{C}, 10^{\circ} \mathrm{C}$, and $15^{\circ} \mathrm{C}$.

Figure 2 shows variation of the energy consumption when the ambient temperature is $5^{\circ} \mathrm{C}, 10^{\circ} \mathrm{C}$, and $15^{\circ} \mathrm{C}$. It indicates that the energy consumption of DX-SAHP increases with the increase of the ambient temperature. When the evaporator temperature increases, the evaporating pressure, the pressure ratio, and the refrigeration mass flow rate of compressor increase, leading to the rise of the compressor energy consumption. The specific values of the energy consumption are $661 \mathrm{~W}, 709 \mathrm{~W}$, and $780 \mathrm{~W}$.

Figure 3 shows the condensing and evaporating heat exchange rate under the three experiment conditions. As the ambient temperature increases from $5^{\circ} \mathrm{C}$ to $15^{\circ} \mathrm{C}$, since the indoor temperature is constant and the evaporator temperature is higher, the condensing temperature rises. The condensing heat exchange rate increases by $350 \mathrm{~W}$, and the evaporating heat exchange rate increases by $261 \mathrm{~W}$. The increment of the condensing heat exchange rate is larger than that of the evaporating heat exchange rate because the energy consumption also increases. The evaporating heat exchange rates are $920 \mathrm{~W}, 1005 \mathrm{~W}$, and $1181 \mathrm{~W}$ (with the REs of

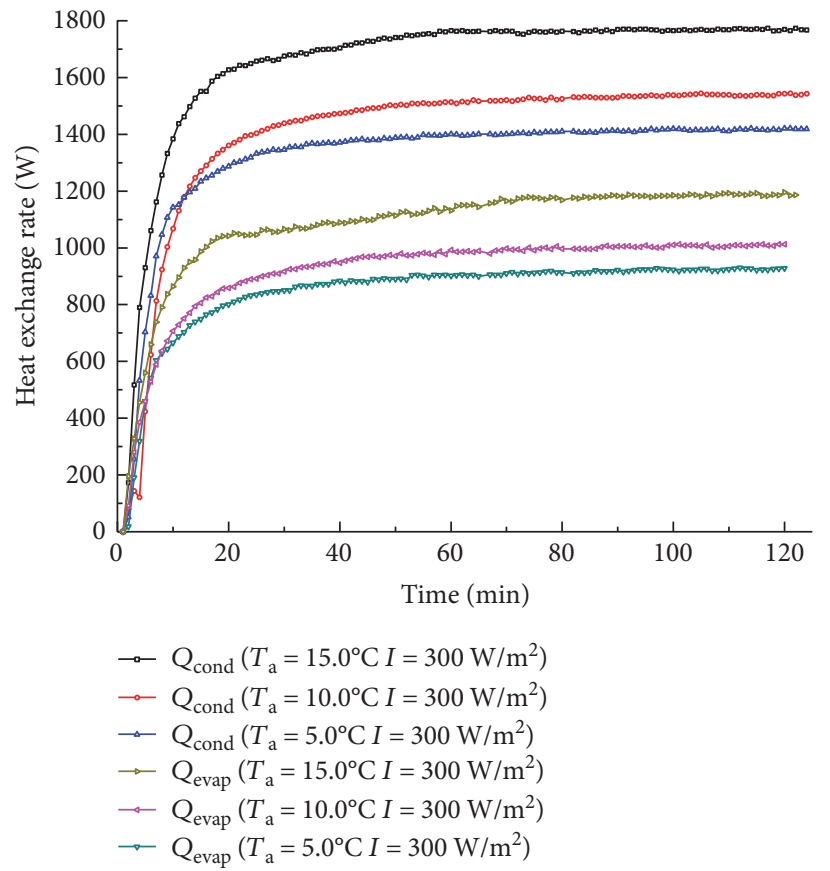

FIGURE 3: Variation of the evaporating and condensing heat exchange rate with the ambient temperature of $5^{\circ} \mathrm{C}, 10^{\circ} \mathrm{C}$, and $15^{\circ} \mathrm{C}$.

$1.9 \%, 1.9 \%$, and $1.8 \%)$ while the condensing heat exchange rates are $1416 \mathrm{~W}, 1537 \mathrm{~W}$, and $1766 \mathrm{~W}$ with the ambient temperature of $5^{\circ} \mathrm{C}, 10^{\circ} \mathrm{C}$, and $15^{\circ} \mathrm{C}$.

Figure 4 shows the variation of COP when the ambient temperature is $5^{\circ} \mathrm{C}, 10^{\circ} \mathrm{C}$, and $15^{\circ} \mathrm{C}$. Under the tested conditions, COP is $2.12,2.18$, and 2.26 . The increase of COP with the increase of the ambient temperature is not significant. This is because the energy consumption also increases, and to some extent, it thwarts the increase of COP although the condensing heat exchange rate increases.

4.2. The Effect of Solar Irradiation. To research the influence of solar irradiation on the thermal performance of the DXSAHP system, the following experiment conditions were chosen. The indoor temperature was $20^{\circ} \mathrm{C} / 15^{\circ} \mathrm{C}(\mathrm{DB} / \mathrm{WB})$, while the outdoor temperature was $15^{\circ} \mathrm{C}$, the relative humidity was $50 \%$, and solar irradiance was $0 \mathrm{~W} \mathrm{~m}^{-2}, 100 \mathrm{~W} \mathrm{~m}^{-2}$, 


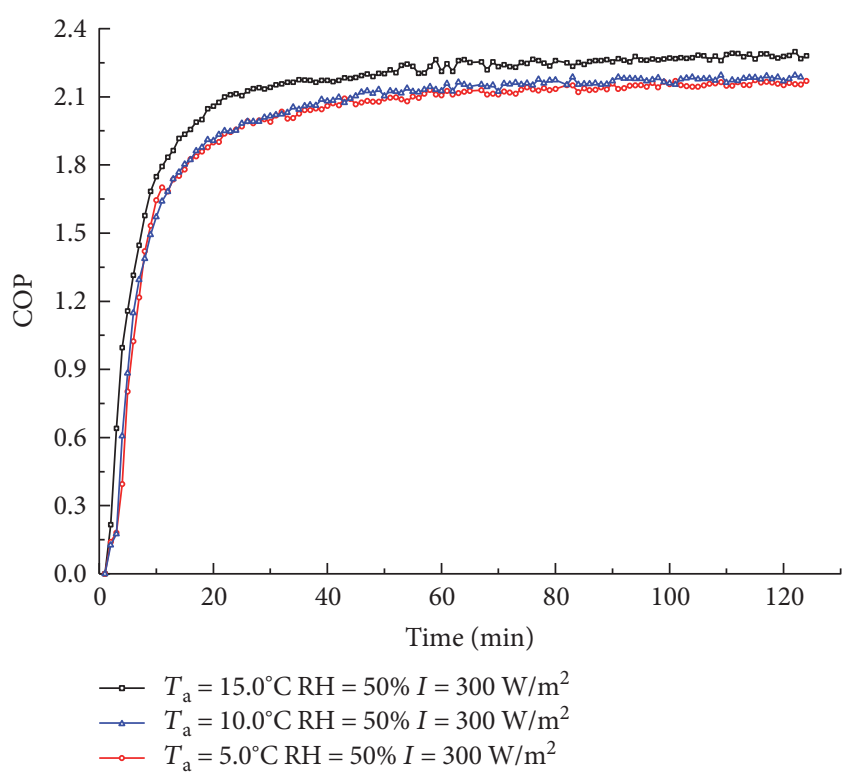

FIgure 4: Variation of COP with the ambient temperature of $5^{\circ} \mathrm{C}$, $10^{\circ} \mathrm{C}$, and $15^{\circ} \mathrm{C}$.

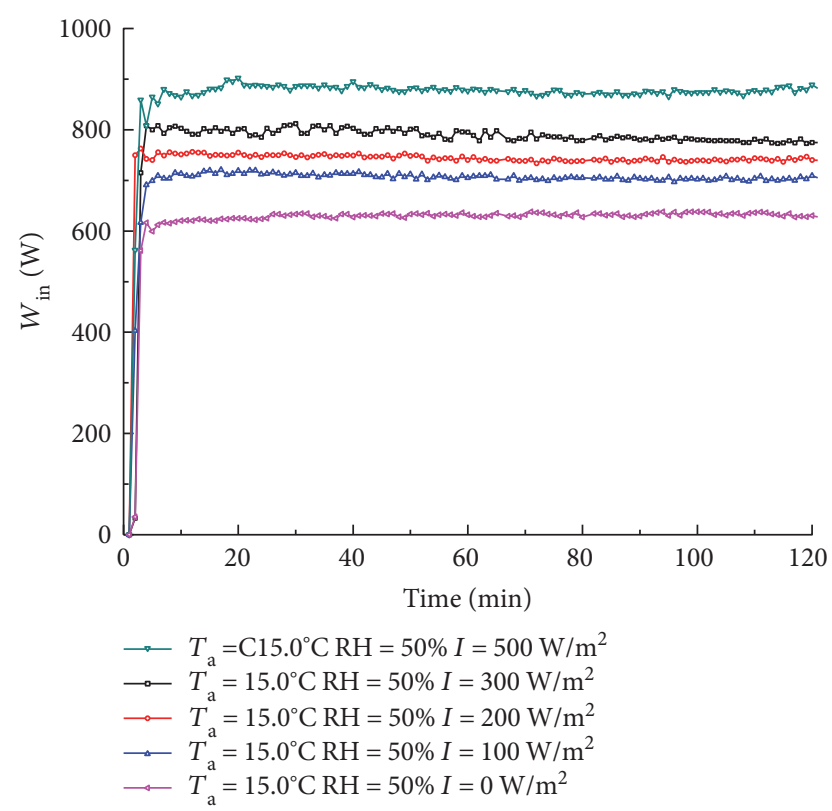

FIgURE 5: Variation of the energy consumption with solar irradiance of $0 \mathrm{~W} \mathrm{~m}^{-2}, 100 \mathrm{~W} \mathrm{~m}^{-2}, 200 \mathrm{~W} \mathrm{~m}^{-2}, 300 \mathrm{~W} \mathrm{~m}^{-2}$, and $500 \mathrm{~W} \mathrm{~m}^{-2}$.

$200 \mathrm{~W} \mathrm{~m}^{-2}, 300 \mathrm{~W} \mathrm{~m}^{-2}$, and $500 \mathrm{~W} \mathrm{~m}^{-2}$. The results are shown in Figures 5-7.

Under solar irradiance of $0 \mathrm{~W} \mathrm{~m}^{-2}, 100 \mathrm{~W} \mathrm{~m}^{-2}, 200 \mathrm{~W} \mathrm{~m}^{-2}$, $300 \mathrm{~W} \mathrm{~m}^{-2}$, and $500 \mathrm{~W} \mathrm{~m}^{-2}$, the evaporator temperature is $7.6^{\circ} \mathrm{C}, 10.0^{\circ} \mathrm{C}, 11.0^{\circ} \mathrm{C}, 12.0^{\circ} \mathrm{C}$, and $16.8^{\circ} \mathrm{C}$, respectively. Therefore, the enhancement of solar irradiation can effectively increase the evaporator temperature. Under solar irradiance of $0 \mathrm{~W} \mathrm{~m}^{-2}, 100 \mathrm{~W} \mathrm{~m}^{-2}, 200 \mathrm{~W} \mathrm{~m}^{-2}$, and $300 \mathrm{~W} \mathrm{~m}^{-2}$ in the tested conditions, the evaporator works at temperature lower

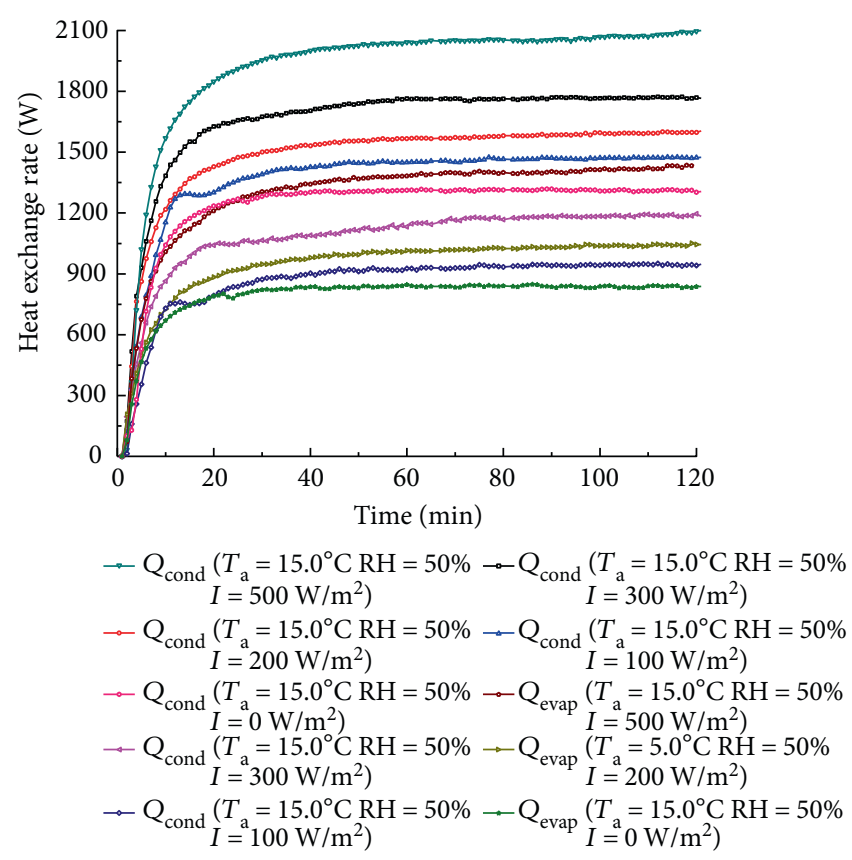

Figure 6: Variation of the evaporating and condensing heat exchange rate with solar irradiance of $0 \mathrm{~W} \mathrm{~m} \mathrm{~m}^{-2}, 100 \mathrm{~W} \mathrm{~m} \mathrm{~m}^{-2}$, $200 \mathrm{~W} \mathrm{~m}^{-2}, 300 \mathrm{~W} \mathrm{~m}^{-2}$, and $500 \mathrm{~W} \mathrm{~m}^{-2}$.

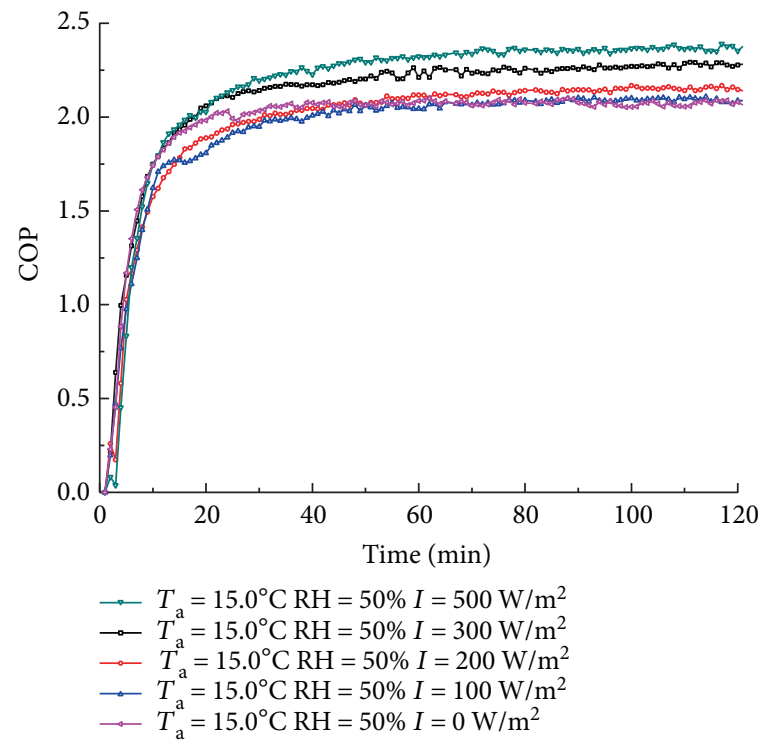

FIGURE 7: Variation of COP with solar irradiance of $0 \mathrm{~W} \mathrm{~m} \mathrm{~m}^{-2}$, $100 \mathrm{~W} \mathrm{~m}^{-2}, 200 \mathrm{~W} \mathrm{~m}^{-2}, 300 \mathrm{~W} \mathrm{~m}^{-2}$, and $500 \mathrm{~W} \mathrm{~m}^{-2}$.

than the ambient temperature. Thus, the evaporatorcollector can absorb energy from both solar irradiation and the ambient. While under solar irradiance of $500 \mathrm{~W} \mathrm{~m}^{-2}$, the evaporator works at temperature higher than the ambient temperature. A portion of the energy that the evaporatorcollector absorbs from solar irradiation is dissipated into the ambient. As the evaporator temperature increases with solar irradiation, the evaporating pressure increases as $392.0 \mathrm{kPa}, 404.2 \mathrm{kPa}, 444.1 \mathrm{kPa}, 473.9 \mathrm{kPa}$, and $590.0 \mathrm{kPa}$. 


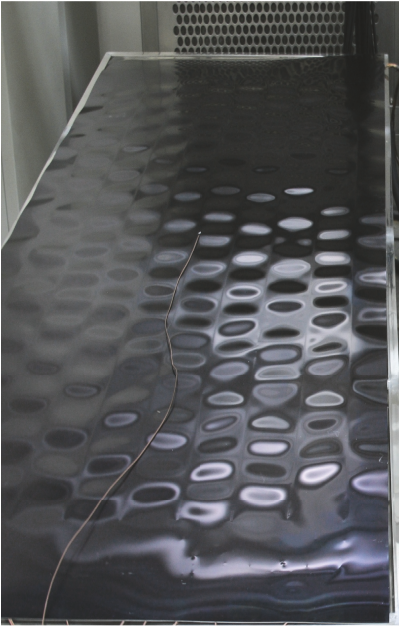

(a)

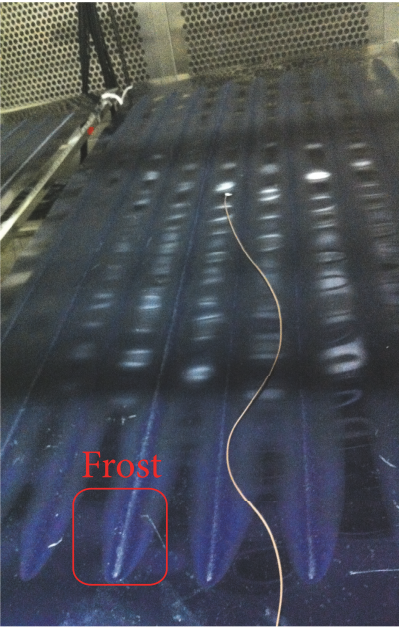

(b)

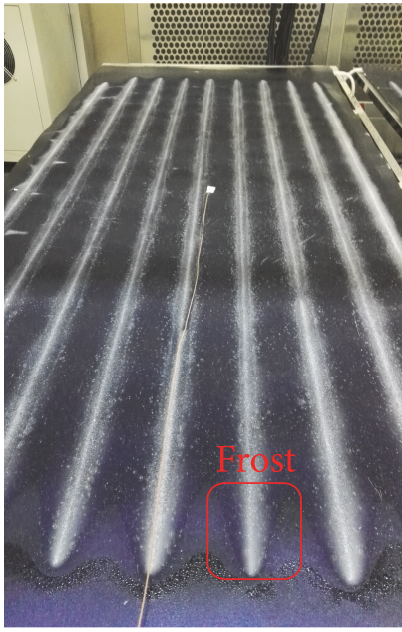

(c)

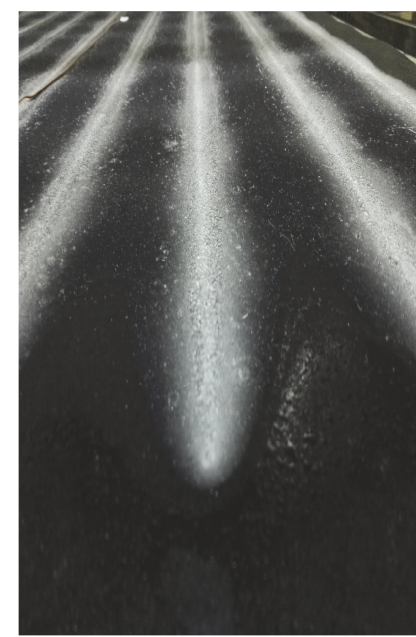

(d)

Figure 8: Photo of the surface of the collectors after 120 min of operating (a) RH=50\%; (b) RH=70\%; (c) RH = 90\%; (d) details of the frost when $\mathrm{RH}=90 \%$.

Therefore, the condensing pressure also rises, with the specific values of $1358.3 \mathrm{kPa}, 1525.9 \mathrm{kPa}, 1633.7 \mathrm{kPa}, 1736.9 \mathrm{kPa}$, and $1954.4 \mathrm{kPa}$.

Figure 5 shows the variation of the energy consumption with solar irradiance of $0 \mathrm{~W} \mathrm{~m}^{-2}, 100 \mathrm{~W} \mathrm{~m}^{-2}, 200 \mathrm{~W} \mathrm{~m}^{-2}$, $300 \mathrm{~W} \mathrm{~m}^{-2}$, and $500 \mathrm{~W} \mathrm{~m}^{-2}$. Since the evaporator temperature rises, the evaporating pressure and the refrigerant mass flow rate also rise, which in turn, causes the rise of the system energy consumption. As shown in Figure 6, the energy consumption is $632 \mathrm{~W}, 707 \mathrm{~W}, 742 \mathrm{~W}, 780 \mathrm{~W}$, and $877 \mathrm{~W}$.

The enhancement of solar irradiation can offer more energy to the evaporator-collector. Although higher evaporator temperature could cause part of the gained solar energy dissipated to the ambient, higher evaporator temperature still results in higher evaporating heat exchange rate, which is presented in Figure 6. The specific values are $835 \mathrm{~W}, 922 \mathrm{~W}$, $1028 \mathrm{~W}, 1181 \mathrm{~W}$, and $1415 \mathrm{~W}$ corresponding to solar irradiance of $0 \mathrm{~W} \mathrm{~m}^{-2}, 100 \mathrm{~W} \mathrm{~m}^{-2}, 200 \mathrm{~W} \mathrm{~m}^{-2}, 300 \mathrm{~W} \mathrm{~m}^{-2}$, and $500 \mathrm{~W} \mathrm{~m}^{-2}$ (with the REs of $1.9 \%, 1.9 \%, 1.9 \%, 1.8 \%$, and $1.8 \%)$. Obviously, the increase of both energy consumption and the evaporating heat exchange rate raises the condensing heat exchange rate. The condensing heat exchange rate changes as $1309 \mathrm{~W}, 1452 \mathrm{~W}, 1585 \mathrm{~W}, 1766 \mathrm{~W}$, and $2073 \mathrm{~W}$. $\mathrm{COP}$ of the system also rises with the increase of solar irradiance, with the specific value as 2.07, 2.09, 2.14, 2.26, and 2.36, as shown in Figure 7.

4.3. The Effect of Relative Humidity. To research the influence of the relative humidity on the thermal performance of the DX-SAHP system, the experiment conditions were the indoor temperature of $20^{\circ} \mathrm{C} / 15^{\circ} \mathrm{C}(\mathrm{DB} / \mathrm{WB})$, while the outdoor temperature was $5^{\circ} \mathrm{C}$, solar irradiance was $0 \mathrm{~W} \mathrm{~m} \mathrm{~m}^{-2}$, and the relative humidity was $50 \%, 70 \%$, and $90 \%$. The results are shown in Figures 8-11.

When the relative humidity was $50 \%$, the surface of the collectors was not frosted after $120 \mathrm{~min}$ of operating, as can be observed in Figure 8(a), while when the relative humidity was $70 \%$ and $90 \%$, frost occurred during the

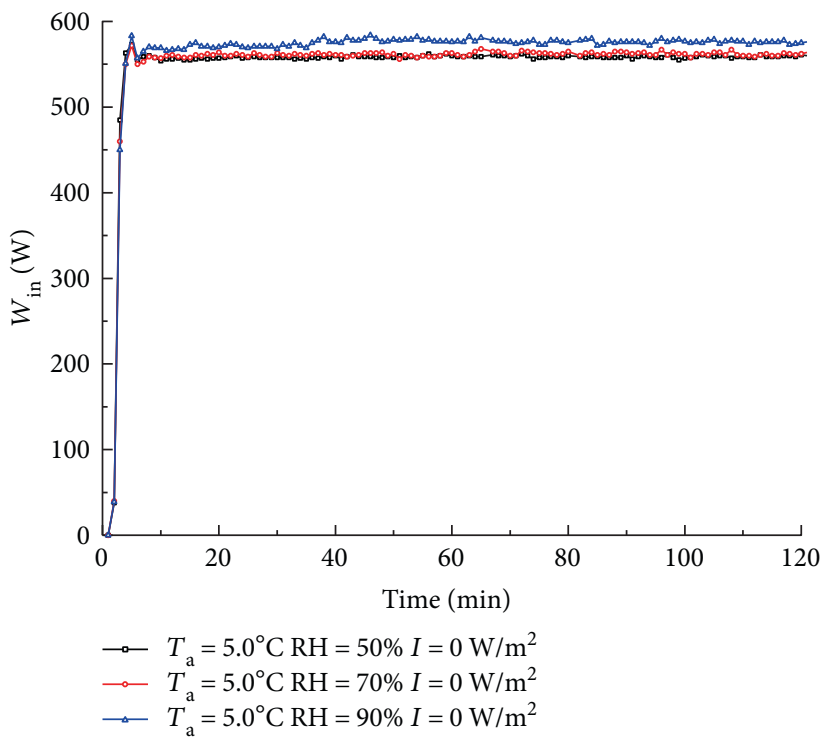

FIGURE 9: Variation of the energy consumption with the relative humidity of $50 \%, 70 \%$, and $90 \%$.

experiment. The frosting process began after the startup of the system. When the relative humidity was $90 \%$, frost was more serious than that when the relative humidity was $70 \%$ after 120 min of operating, as presented in Figures 8(b) and 8(c). The details of the frost are shown in Figure 8(d). The frost is not column shaped, but in the form of ice particles.

Figures 9-11 show the energy consumption, heat exchange rate, and COP when the relative humidity is $50 \%, 70 \%$, and $90 \%$. Although the collectors are frosted when the relative humidity is $70 \%$ and $90 \%$, the heating performance of the system did not decrease significantly, as presented in Figures 9-11. The reason is that the frosting process is slow and the collectors are not seriously frosted 


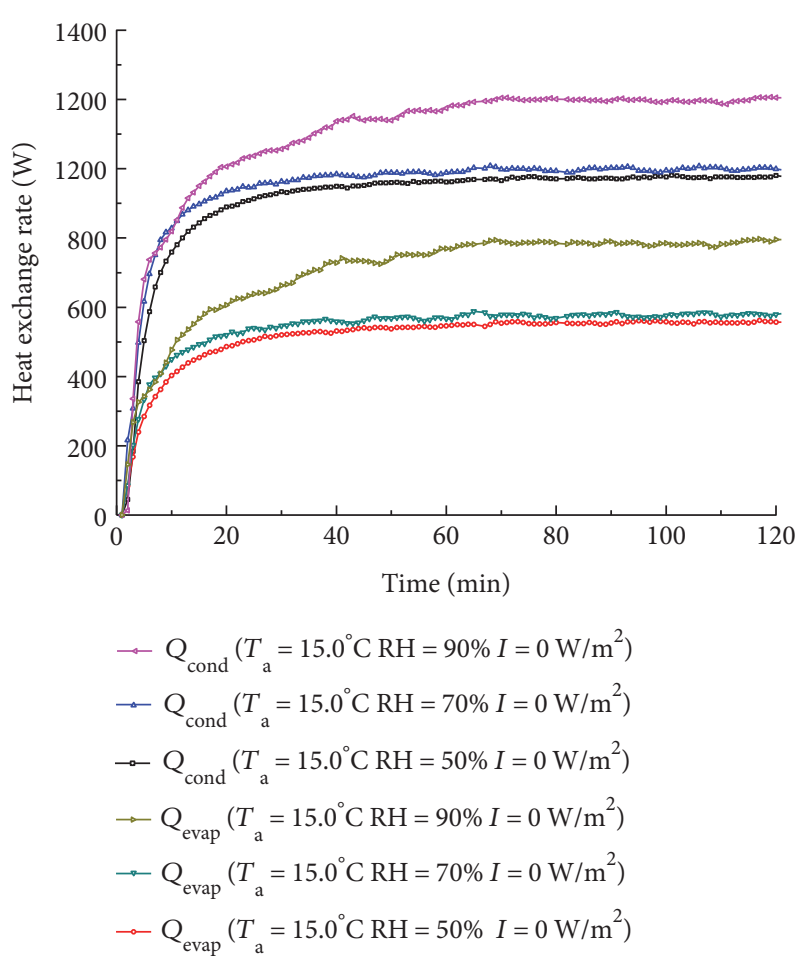

Figure 10: Variation of the evaporating and condensing heat exchange rate with the relative humidity of $50 \%, 70 \%$, and $90 \%$.

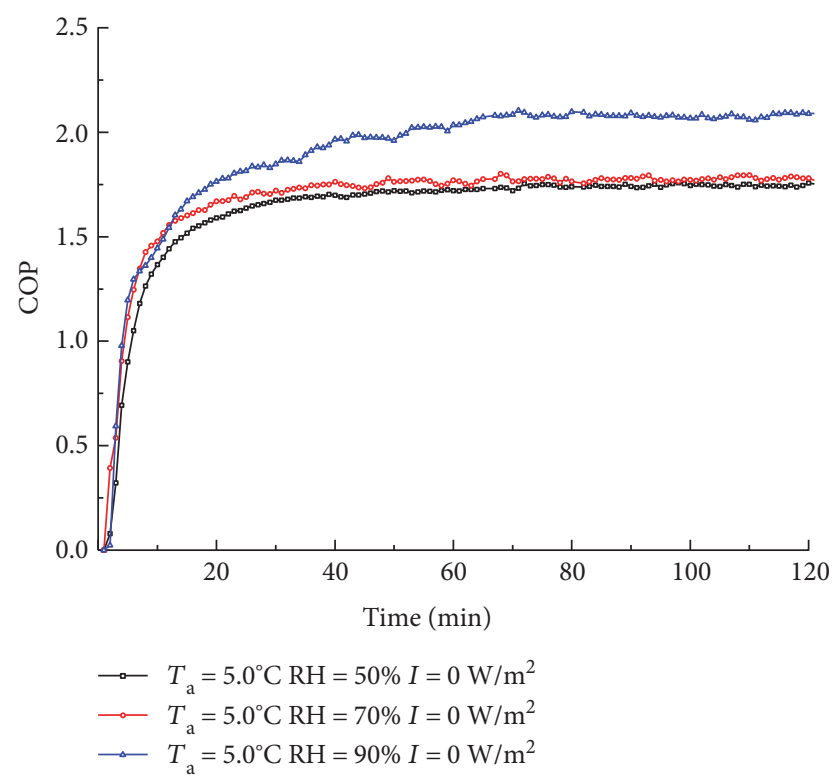

FIGURE 11: Variation of the energy consumption with the relative humidity of $50 \%, 70 \%$, and $90 \%$.

in $120 \mathrm{~min}$, because the heat exchange area of the collectors is large and the heat exchange mode is natural convection, not forced convection.

The system energy consumption increases with the increase of the relative humidity, which is shown in Figure 9. Because as the relative humidity rises, frost forms on the collectors, and the condensing latent heat raises the evaporating pressure, leading to the increase of the compressor energy consumption. On the other hand, since the frost is slight, the difference between the values is small, with the values of 559 W, 562 W, and 577 W. As shown in Figure 10, when the relative humidity rises, the evaporating and condensing heat exchange rate increases. The condensing heat exchange rates are $975 \mathrm{~W}, 998 \mathrm{~W}$, and $1191 \mathrm{~W}$, with the relative humidity of $50 \%, 70 \%$, and $90 \%$. The evaporating heat exchange rates are $556 \mathrm{~W}, 577 \mathrm{~W}$, and $779 \mathrm{~W}$ (with the REs of $2.2 \%, 2.1 \%$, and $1.9 \%$ ). Because the frost formed during the experiments is not thick, thermal resistance between the evaporator and the ambient increases little. Besides, the condensing process brings latent heat which helps the heat exchange between the evaporator and the ambient. Frost deposition increases the roughness of the surface, which is also good for the heat exchange. Consequently, the heat exchange is improved by the frosting process. The differences between the evaporating and condensing heat exchange rates when the relative humidity is $50 \%$ and $70 \%$ are not significant. When the relative humidity is $50 \%$, no frost occurs. The amount of frost is very little when the relative humidity is of $70 \%$; hence, the system performance is not significantly improved. The same reason can also explain the difference of COP between the two cases, with the values of 1.75 and 1.78 when the relative humidity is $50 \%$ and $70 \%$. In comparison, the evaporating heat exchange rate and COP are raised by $35.0 \%$ and $16.3 \%$ as the relative humidity rising from $70 \%$ to $90 \%$, because frost when the relative humidity is $90 \%$ is more serious than that when the relative humidity is $70 \%$, as can be observed comparing Figures $8(\mathrm{~b})$ and $8(\mathrm{c})$.

The phenomenon of the frosting improving the system performance is opposite to the common phenomenon of heat pumps. In the previous work of Guo et al. [23], the frost growth of heat pump systems was divided into three stages. In the first stage, water freezes into a thin ice layer on the evaporator surface, and the granular ices grow gradually to form ice crystals. The performance of the heat pump can be improved. In the second stage, the radius of the ice crystals grows and the performance of the heat pump system is not significantly influenced. In the third stage, the frost thickness grows rapidly, leading to a sharp decrease of the system performance. For common heat pumps, frosting can be fast and serious. The frosting process enters the third stage, and the performance of the system decays rapidly. While for the tested DX-SAHP system, the frosting process is not as serious as common heat pumps due to the flat plate structure of the evaporator. The frost formed during the experiment was not serious, which is in the first stage. Therefore, the frosting process benefits the performance of the DX-SAHP system, as can be seen from the above result analysis.

\section{Conclusions}

To research the independent influence of ambient temperature, solar irradiation, and relative humidity on the thermal performance of the direct-expansion solar-assisted heat pump (DX-SAHP) system, experiments on a DX-SAHP 
system applying bare plate evaporators for space heating are conducted in the enthalpy difference lab with a solar simulator, with the ambient conditions stable. The heating capacity of the DX-SAHP system is measured by an air-enthalpy type calorimeter with high degree of accuracy. The present study tested the DX-SAHP system under winter meteorological conditions, with the ambient temperature of $5^{\circ} \mathrm{C}, 10^{\circ} \mathrm{C}$, and $15^{\circ} \mathrm{C}$ when the relative humidity was $50 \%$ and solar irradiance was $300 \mathrm{~W} \mathrm{~m}^{-2}$. Solar irradiance was $0 \mathrm{~W} \mathrm{~m}^{-2}, 100 \mathrm{~W}$ $\mathrm{m}^{-2}, 200 \mathrm{~W} \mathrm{~m}^{-2}, 300 \mathrm{~W} \mathrm{~m}^{-2}$, and $500 \mathrm{~W} \mathrm{~m}^{-2}$ with the ambient temperature of $15{ }^{\circ} \mathrm{C}$ and the relative humidity of $50 \%$. The relative humidity was $50 \%, 70 \%$, and $90 \%$ when the ambient temperature was $5^{\circ} \mathrm{C}$ and solar irradiance was $0 \mathrm{~W} \mathrm{~m}^{-2}$.

(1) When the ambient temperature changes as $5^{\circ} \mathrm{C}, 10^{\circ} \mathrm{C}$, and $15^{\circ} \mathrm{C}$ with solar irradiance of $300 \mathrm{~W} \mathrm{~m}^{-2}$ and the relative humidity of $50 \%$, the influence of ambient temperature on the system performance is analyzed. The rise of the ambient temperature leads to higher evaporating pressure and higher evaporator temperature, with the value of $3.1^{\circ} \mathrm{C}$, $7.4^{\circ} \mathrm{C}$, and $12.0^{\circ} \mathrm{C}$. The condensing pressure, energy consumption, the evaporating and condensing heat exchange rate, and COP of the system increase accordingly. The energy consumption is $661 \mathrm{~W}$, $709 \mathrm{~W}$, and $774 \mathrm{~W}$, and the condensing heat exchange rate is $1416 \mathrm{~W}, 1537 \mathrm{~W}$, and $1766 \mathrm{~W}$. COP increases as $2.12,2.18$, and 2.26 , respectively.

(2) When solar irradiance changes as $0 \mathrm{~W} \mathrm{~m} \mathrm{~m}^{-2}, 100 \mathrm{~W}$ $\mathrm{m}^{-2}, 200 \mathrm{~W} \mathrm{~m} \mathrm{~m}^{-2}, 300 \mathrm{~W} \mathrm{~m}^{-2}$, and $500 \mathrm{~W} \mathrm{~m}^{-2}$ with the ambient temperature of $15^{\circ} \mathrm{C}$ and the relative humidity of $50 \%$, the influence of solar irradiation on the system performance is analyzed. Higher solar irradiation could improve the evaporating pressure and the evaporator temperature, with the values of 7. $6^{\circ} \mathrm{C}, 10.0^{\circ} \mathrm{C}, 11.0^{\circ} \mathrm{C}, 12.0^{\circ} \mathrm{C}$, and $16.8^{\circ} \mathrm{C}$. Therefore, the energy consumption, the condensing and evaporating heat exchange rate, and COP also rise. The energy consumption is $632 \mathrm{~W}, 707 \mathrm{~W}, 742 \mathrm{~W}$, $780 \mathrm{~W}$, and $877 \mathrm{~W}$. The condensing heat exchange rate changes as $1309 \mathrm{~W}, 1452 \mathrm{~W}, 1585 \mathrm{~W}, 1766 \mathrm{~W}$, and $2073 \mathrm{~W}$. COP of the system is $2.07,2.09,2.14$, 2.26 , and 2.36 .

(3) When the relative humidity is $50 \%, 70 \%$, and $90 \%$, the ambient temperature is $5^{\circ} \mathrm{C}$, and solar irradiance is $0 \mathrm{~W} \mathrm{~m} \mathrm{~m}^{-2}$, the influence of relative humidity is analyzed. With the relative humidity of $50 \%$, no frost occurred on the collectors. While with the relative humidity of $70 \%$ and $90 \%$, the collectors were frosted, and under the latter condition, frost is more serious. Results show that frost did not degrade but improved the thermal performance of the DXSAHP system, because the frost is not serious after $120 \mathrm{~min}$ of operating. The increase of the relative humidity from $70 \%$ to $90 \%$ raises the evaporating heat exchange rate by $35.0 \%$ and increases COP by $16.3 \%$, from 1.78 to 2.07 .

\section{Nomenclature}

Symbols

$A_{\mathrm{c}}$ : Total collector surface area, $\mathrm{m}^{2}$

COP: Coefficient of performance

$D_{\mathrm{n}}$ : Humidity ratio of air at the nozzle

$h: \quad$ Enthalpy, $\mathrm{J} \mathrm{kg}^{-1}$.

I: $\quad$ Solar irradiance, $\mathrm{W} \mathrm{m}^{-2}$

$m$ : $\quad$ Mass flow rate, $\mathrm{kg} \mathrm{s}^{-1}$

$P$ : $\quad$ Pressure, $\mathrm{kPa}$

Q: $\quad$ Rate of heat transfer, W

RH: Relative humidity, \%

$t$ : Time, min

T: $\quad$ Temperature, ${ }^{\circ} \mathrm{C}$

$T_{\mathrm{a}}$ : Ambient temperature, ${ }^{\circ} \mathrm{C}$

$T_{\mathrm{e}}$ : $\quad$ Evaporating temperature, ${ }^{\circ} \mathrm{C}$

$V_{\mathrm{a}}$ : Air volume flow rate at the nozzle, $\mathrm{m}^{3} \mathrm{~s}^{-1}$

$V_{\mathrm{n}}$ : Specific volume of air at the nozzle, $\mathrm{m}^{3} \mathrm{~kg}^{-1}$

$W: \quad$ Energy consumption, $\mathrm{W}$

$\eta$ : Efficiency.

Subscripts

cond: Condenser

evap: Evaporator

in: Inlet

in-a: Air inlet

out-a: Air outlet

out: Outlet

comp: Compressor.

\section{Conflicts of Interest}

The authors declare that they have no conflicts of interest.

\section{Acknowledgments}

This work is supported by the National Natural Science Foundation of China (no. 51378483), Projects in the National Science \& Technology Pillar Program during the Twelfth Five-Year Plan Period (no. 2015BAA02B03), and DongGuan Innovative Research Team Program (no. 2014607101008).

\section{References}

[1] O. Ozgener and A. Hepbasli, "A review on the energy and exergy analysis of solar assisted heat pump systems," Renewable and Sustainable Energy Reviews, vol. 11, no. 3, pp. 482496, 2007.

[2] K. J. Chua, S. K. Chou, and W. M. Yang, "Advances in heat pump systems: a review," Applied Energy, vol. 87, no. 12, pp. 3611-3624, 2010.

[3] Z. M. Amin and M. N. A. Hawlader, "A review on solar assisted heat pump systems in Singapore," Renewable and Sustainable Energy Reviews, vol. 26, pp. 286-293, 2013.

[4] M. Z. H. Khan, M. R. Al-Mamun, S. Sikdar, P. K. Halder, and M. R. Hasan, "Design, fabrication, and efficiency study of a novel solar thermal water heating system: towards sustainable 
development," International Journal of Photoenergy, vol. 2016, Article ID 9698328, 8 pages, 2016.

[5] Y. Bai, T. T. Chow, C. Ménézo, and P. Dupeyrat, “Analysis of a hybrid PV/thermal solar-assisted heat pump system for sports center water heating application," International Journal of Photoenergy, vol. 2012, Article ID 265838, 13 pages, 2012.

[6] P. Sporn and E. R. Ambrose, "The heat pump and solar energy," in Proceeding of the World Symposium on Applied Solar Energy, 1955.

[7] S. K. Chaturvedi and J. Y. Shen, "Thermal performance of a direct expansion solar-assisted heat-pump," Solar Energy, vol. 33, no. 2, pp. 155-162, 1984.

[8] B. J. Huang and J. P. Chyng, "Performance characteristics of integral type solar-assisted heat pump," Solar Energy, vol. 71, no. 6, pp. 403-414, 2001.

[9] K. I. Krakow and S. Lin, "A solar source heat pump with refrigerant-cooled solar collectors for cold climates," International Journal of Refrigeration, vol. 6, no. 1, pp. 20-33, 1983.

[10] S. Ito, N. Miura, and K. Wang, "Performance of a heat pump using direct expansion solar collectors," Solar Energy, vol. 65, no. 3, pp. 189-196, 1999.

[11] M. N. A. Hawlader, S. K. Chou, and M. Z. Ullah, "The performance of a solar assisted heat pump water heating system," Applied Thermal Engineering, vol. 21, no. 10, pp. 1049-1065, 2001.

[12] J. P. Chyng, C. P. Lee, and B. J. Huang, "Performance analysis of a solar-assisted heat pump water heater," Solar Energy, vol. 74, no. 1, pp. 33-44, 2003.

[13] G. Y. Xu, X. S. Zhang, and S. M. Deng, "A simulation study on the operating performance of a solar-air source heat pump water heater," Applied Thermal Engineering, vol. 26, no. 11-12, pp. 1257-1265, 2006.

[14] Y. W. Li, R. Z. Wang, J. Y. Wu, and Y. X. Xu, "Experimental performance analysis and optimization of a direct expansion solar-assisted heat pump water heater," Energy, vol. 32, no. 8, pp. 1361-1374, 2007.

[15] X. Q. Kong, D. Zhang, Y. Li, and Q. M. Yang, “Thermal performance analysis of a direct-expansion solar-assisted heat pump water heater," Energy, vol. 36, no. 12, pp. 6830-6838, 2011.

[16] T. T. Chow, G. Pei, K. F. Fong, Z. Lin, A. L. S. Chan, and M. He, "Modeling and application of direct-expansion solar-assisted heat pump for water heating in subtropical Hong Kong," Applied Energy, vol. 87, no. 2, pp. 643-649, 2010.

[17] X. L. Sun, J. Wu, Y. Dai, and R. Wang, "Experimental study on roll-bond collector/evaporator with optimized-channel used in direct expansion solar assisted heat pump water heating system," Applied Thermal Engineering, vol. 66, no. 1-2, pp. 571-579, 2014.

[18] J. Fernandez-Seara, C. Piñeiro, J. Alberto Dopazo, F. Fernandes, and S. PXB, "Experimental analysis of a direct expansion solar assisted heat pump with integral storage tank for domestic water heating under zero solar radiation conditions," Energy Conversion and Management, vol. 59, pp. 1-8, 2012.

[19] Y. H. Kuang and R. Z. Wang, "Performance of a multifunctional direct-expansion solar assisted heat pump system," Solar Energy, vol. 80, no. 7, pp. 795-803, 2006.

[20] D. Zhang, Q. B. Wu, J. P. Li, and X. Q. Kong, "Effects of refrigerant charge and structural parameters on the performance of a direct-expansion solar-assisted heat pump system," Applied Thermal Engineering, vol. 73, no. 1, pp. 522-528, 2014.
[21] W. Z. Huang, J. Ji, N. Xu, and G. Li, "Frosting characteristics and heating performance of a direct-expansion solar-assisted heat pump for space heating under frosting conditions," Applied Energy, vol. 171, pp. 656-666, 2016.

[22] Y. W. Li, R. Z. Wang, J. Y. Wu, and Y. X. Xu, "Experimental performance analysis on a direct-expansion solar-assisted heat pump water heater," Applied Thermal Engineering, vol. 27, no. 17-18, pp. 2858-2868, 2007.

[23] X. M. Guo, Y.-G. Chen, W.-H. Wang, and C.-Z. Chen, "Experimental study on frost growth and dynamic performance of air source heat pump system," Applied Thermal Engineering, vol. 28 , no. 17-18, pp. 2267-2278, 2008. 

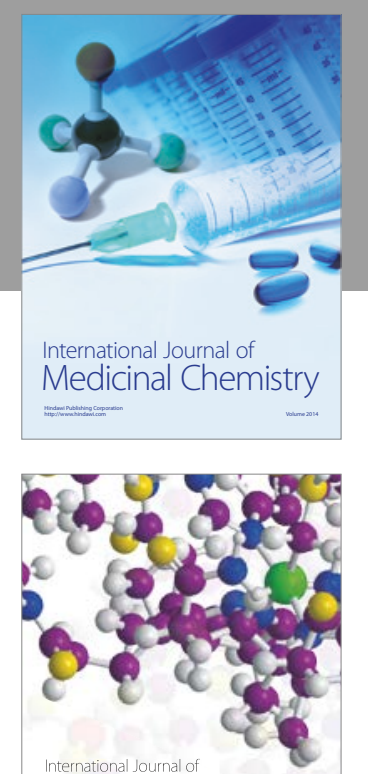

Carbohydrate Chemistry

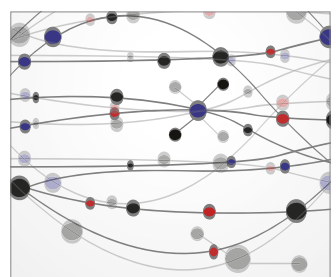

The Scientific World Journal
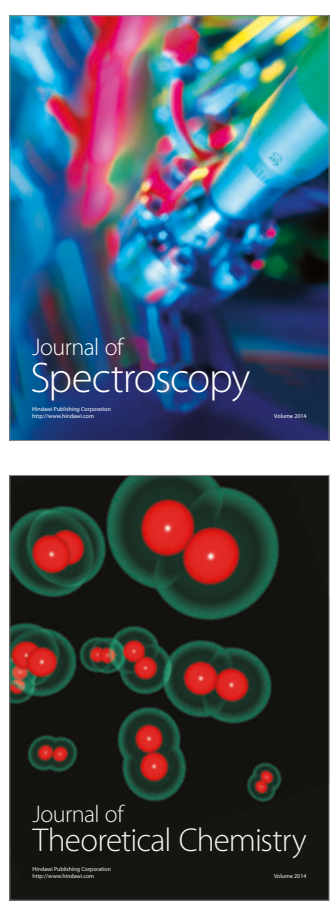
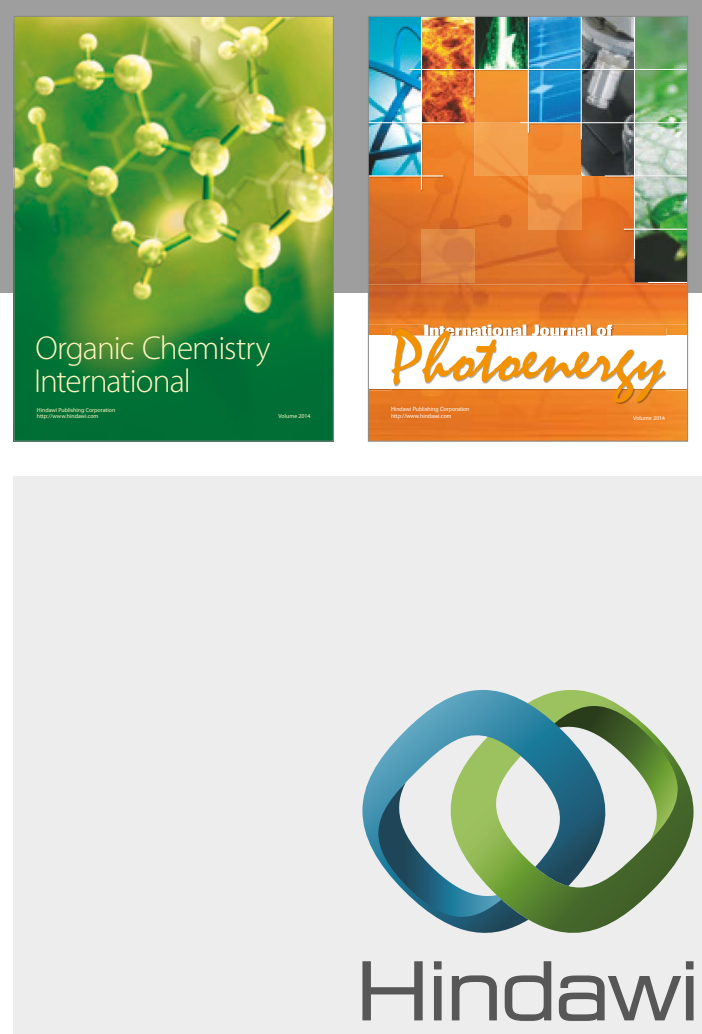

Submit your manuscripts at

https://www.hindawi.com

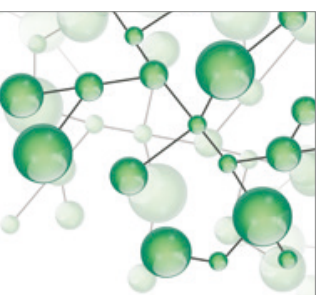

International Journal of

Inorganic Chemistry

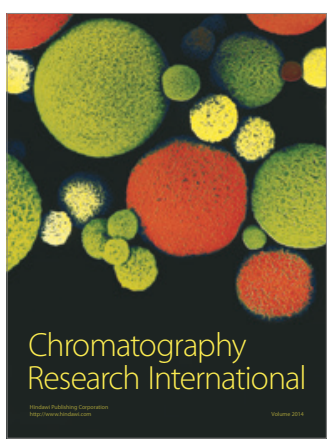

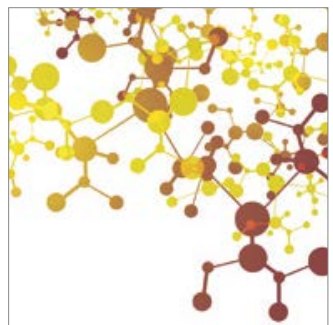

Applied Chemistry
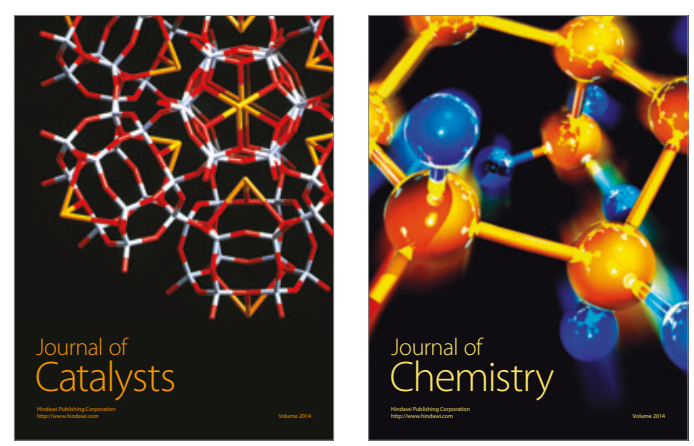
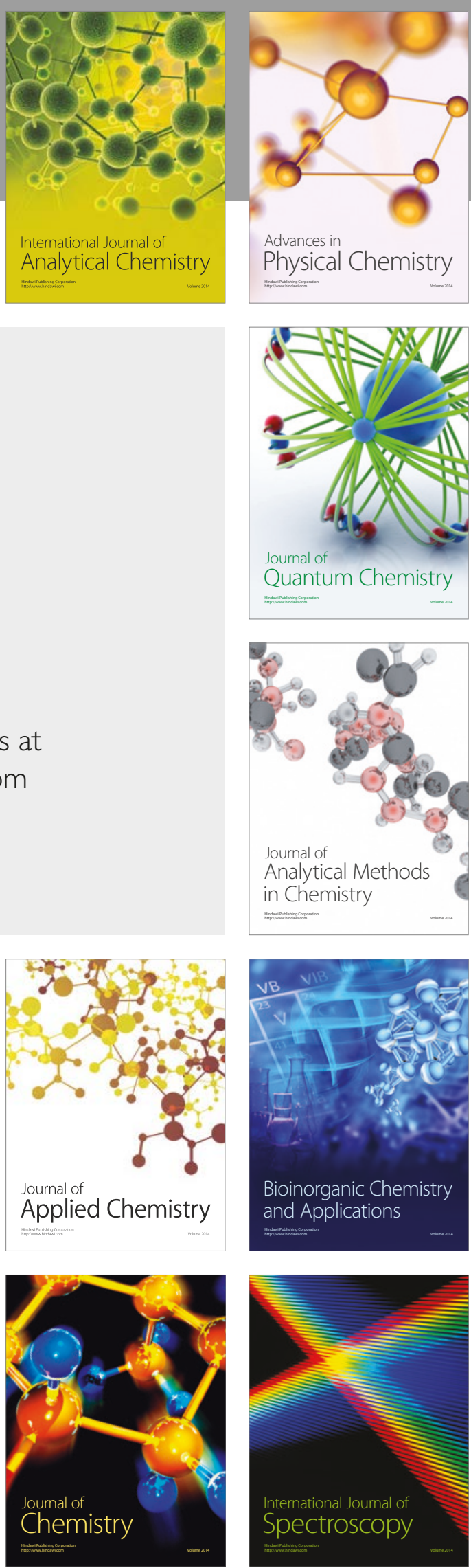